\title{
Asian Immigration to the European Union, United States and Canada: An Initial Comparison
}

\author{
Anna Platonova • Giuliana Urso
}

Published online: 5 January 2013

(C) CEEUN 2013

\begin{abstract}
Immigration from Asia has been an important element of the migratory picture in both Europe and North America for years. In particular, some of the most skilled migrants originate from Asia, but also some of the most deprived and vulnerable. Immigration policies of the developed countries have been trying to woo the highly skilled migrants for some time, which becomes increasingly difficult in the light of growing intra-Asian opportunities and notable returns to China and India in particular. The article provides an initial snapshot of evidence on the diversity of migrant population in the EU and North America from the main Asian sending countries in terms of demographics, skill level, purpose of entry and labour market outcomes. This data is analyzed against the key characteristics of the national and regional policy frameworks to draw some initial policy considerations.
\end{abstract}

Keywords Labour migration · Integration · Asian migration · Competition for talents · European Union

\section{Introduction: Migration Outlook for Asia}

The global number of international migrants has been constantly growing in recent decades, now reaching around 214 million (UN DESA, 2010). Asia is the site of intensive international migration within and outside the region, with many countries emerging as both important sources and destinations of migration flows. Being the

A. Platonova · G. Urso ( $\square)$

Regional Office of the International Organization for Migration, Brussels, Belgium e-mail: gurso@iom.int
A. Platonova
e-mail: aplatonova@iom.int 
Table 1 Net migration for Asia, 2005-2010

\begin{tabular}{lll}
\hline Country or area & $\begin{array}{l}\text { Average annual net } \\
\text { migration (thousand) }\end{array}$ & $\begin{array}{l}\text { Average annual net migration } \\
\text { rate (per 1,000 population) }\end{array}$ \\
\hline Asia & -1075.7 & -0.3 \\
Central Asia & -160.0 & -2.7 \\
Eastern Asia & -291.5 & -0.2 \\
South-Eastern Asia & -293.3 & -0.5 \\
Southern Asia & -575.1 & -0.3 \\
Western Asia & 244.3 & 1.1 \\
China & -346.2 & -0.3 \\
Republic of Korea & -6.0 & -0.1 \\
Philippines & -180.0 & -2.0 \\
Vietnam & -40.0 & -0.5 \\
India & -200.0 & -0.2 \\
Pakistan & -283.1 & -1.6 \\
\hline
\end{tabular}

Source UN DESA (2009a), International Migration, Wallchart

a For statistical purposes, the data for China do not include Hong Kong and Macao, Special Administrative Regions (SAR) of China

most populous world region with 4,121 million of inhabitants (2009), Asia is by far the primary source of international migration globally, with on average 1.3 million of migrants originating from Asia annually in 2000-2010 (UN DESA 2009b). Although this figure represents only some $0.3 \%$ of the Asian population ${ }^{1}$ (Table 1), the impact of this immigration on the rest of the world is significant, and potentially even more crucial considering the lack of reliable data on undocumented migrants and the limited data on international (regular) migration collected by some countries. Moreover, the impact in the countries of origin is also quite substantial: Asia accounts for $62 \%$ of all remittance flows to developing countries, with officially recorded remittances flows estimated to USD 200 billion in 2011 (Ratha 2012). The remittance flows to Asia remained flat during the economic crisis (2009), but grew robustly immediately after. India and China are the main recipients of remittances worldwide, with 64 and 62 billion USD estimated for 2011 respectively (World Bank 2012).

Migration patterns and respective challenges vary in the Asian region due to the diversity of the economic and political context. Until 1960, Asia registered a positive net migration. Lately, redistribution occurred in international migration flows within and from Asia. While Western Asia has continuously attracted migrant workers to its oil industries, migration from the former colonies (primarily India, Pakistan, Indonesia and Vietnam) intensified towards the United Kingdom, The Netherlands and France. In addition, war and civil strife have caused significant refugee flows within Asia (UN DESA 2005).

\footnotetext{
${ }^{1}$ In 2005-2010.
} 
Labour immigration into the Asian emerging economies highlights the increasing importance of South-South migration movements, such as the Bangladesh-India corridor (3.5 million registered migrants in 2005), and the ever more pertinent need for further strengthening of migration management in the region (IOM 2010a). Intra-regional movements account for three quarters of migration to Japan and Korea, though India, Pakistan, Hong Kong, Singapore and Malaysia are also important destinations for migrants from the region (Integration: Building Inclusive Society (IBIS), 2010).

This article provides an initial snapshot of evidence on the diversity of migrant population in the EU and North America from the main Asian sending countries in terms of demographics, skill level, purpose of entry and labour market outcomes. This data is analyzed against the key characteristics of the national and regional policy frameworks to draw some initial considerations relevant for the policymakers in the current and potential immigrant destination countries.

\section{Top Six Countries of Origin}

To analyze the Asian migration, including mapping its composition and impact in the countries of destination, and identifying trajectories and pull factors in the migration process, we have selected the six main source countries for Asian ${ }^{2}$ immigrants in the European Union (EU), Canada and United States (US), namely China, India, Pakistan, Philippines, Republic of Korea (hereinafter also mentioned as Korea) and Vietnam. ${ }^{3}$ This is done with the purpose of initial comparative analysis of the Asian migration patterns in Europe and North America as two important global immigration regions.

Historical, economic or geopolitical factors play a role in explaining the distribution of Asians worldwide: as an unincorporated territory of the US in the first half of the 20th century, Filipinos where exempted from restriction on admission; India as part of the Commonwealth maintained privileged position with the United Kingdom; during the cold war Eastern European members of the communist bloc created politically friendly relations with Vietnam, in addition after the regime change in 1975, a consistent number of South Vietnamese went to the US.

At the beginning of this century, the main destination countries for Asian migrants were the US, Canada and the UK. In 2010, while US and Canada still

\footnotetext{
${ }^{2}$ If not otherwise outlined, in this article we refer to 'Asian countries' to indicate the six countries analyzed, namely China, India, Pakistan, Philippines, Republic of Korea, and Vietnam.

3 As is often the case in migration studies, some of the main difficulties in this analysis stem from the availability of data and their comparability. The analysis presented is indeed the result of the collection of some relevant data from different sources (OECD databases, national censuses, Eurostat, UN PD, UN DESA). Whenever possible, we have used the same source in order to minimize the statistical error in comparison of data from various sources, which often implies the use of different methods of data collection. For the sake of comparison, we have selected 2010 as the year of reference, this being the last year with available data for all the countries of destination. The most recent data have been used whenever this year of reference was not available. In addition, there are significant numbers of irregular immigrant population in some of the destination countries, which are not reflected in the official statistics.
} 
Table 2 Main destination countries for Asian migrants, 2000-2010

\begin{tabular}{lllllll}
\hline \multirow{6}{*}{$\begin{array}{l}\text { Main } \\
\text { destination }\end{array}$} & $\begin{array}{l}\text { Av } \\
\text { thousand }\end{array}$ & $\begin{array}{l}\text { Main } \\
\text { destination } \\
2000\end{array}$ & $\begin{array}{l}\text { Av } \\
\text { thousand }\end{array}$ & $\begin{array}{l}\text { Main } \\
\text { destination } \\
2010\end{array}$ & $\begin{array}{l}\text { Change } \\
2000-2010 \text { (\%) }\end{array}$ \\
\hline China & US & 45.585 & US & 70.863 & US & 55.5 \\
& Canada & 36.75 & Canada & 30.195 & Canada & -17.8 \\
& UK & 18.564 & Italy & 22.866 & Italy & a \\
& US & 41.903 & US & 69.162 & US & 65.1 \\
& Canada & 26.123 & UK & 68 & UK & 296.5 \\
& UK & 17.15 & Canada & 30.25 & Canada & 15.8 \\
Korea & US & 15.721 & US & 22.227 & US & 41.4 \\
& Canada & 7.639 & Canada & 5.54 & Canada & -27.5 \\
& UK & 4.339 & Germany & 4.096 & Germany & 68.6 \\
Pakistan & US & 14.504 & US & 58.173 & US & 301.1 \\
& Canada & 14.201 & Canada & 36.575 & Canada & 157.6 \\
& UK & 9.461 & Sweden & 21.725 & Sweden & b \\
Philippines & US & 42.343 & US & 58.173 & US & 37.4 \\
& Canada & 10.119 & Canada & 36.575 & Canada & 261.4 \\
& Italy & 6.71 & Italy & 10.745 & Italy & 60.1 \\
\multirow{6}{*}{ Vietnam } & US & 26.553 & US & 30.632 & US & 15.4 \\
& Germany & 5.867 & Germany & 4.31 & Germany & -26.5 \\
& Canada & 1.8 & UK & 3 & UK & a \\
\hline
\end{tabular}

Source Author Elaboration on OECD International Migration Database on Migration

$N B$ No data available for Bulgaria, Cyprus, Estonia, Greece, Ireland, Latvia, Lithuania, Malta, Romania, Slovenia

${ }^{\text {a }}$ Data not available for 2000

${ }^{\mathrm{b}}$ Higher than eight-fold increase

remain the first two main countries of destination, the third country in Europe changes for each nationality. Therefore, if Italy attracts Filipinos (as already in 2000) and Chinese, Germany is a pull country for Koreans and Sweden for Pakistanis. Migrants from Vietnam have favoured Germany and the UK in 2010, leaving Canada in the fourth position (Table 2). However, overall the 27 countries of the European Union attracted in 2010 more Asian migrants than the US and Canada, with an inflow of 358,782, in comparison with 269,315 into the US and 109,445 into Canada. China represented almost $10 \%$ of total immigration flows to the OECD in 2010, and over $25 \%$ in some destination countries.

In the last decade, flows from India and Pakistan augmented significantly in the selected countries of destination (by 111.0 and $92.4 \%$ respectively). Canada has seen a decrease in the numbers of Chinese and Koreans, and an increase instead in new arrivals from the Philippines and Pakistan. In the EU, a substantial increase has been registered for Indians in the UK (nearly 4 times), and to a less extent for Koreans in Germany and Filipinos in Italy. This trend is confirmed by a previous study, which underlined that although Europe was not a traditionally preferred 
destination for Asian migrants (except perhaps for the UK), an increase in the migrant inflows from the Asian continent has been recently observed in Northern Europe (Finland and Sweden), Southern Europe (Portugal, Spain, Italy) and in the new EU Member States (the Czech Republic and Poland) (Platonova and Urso 2011).

In terms of stock, the major receiving country for Asian migrants globally is the US. In 2010, the share of Asians in the US comprised nearly $30 \%$ of the total foreignborn population. The number of Asian population increased from 8.2 million in 2000-2011.3 million in 2010, while 50 years ago it accounted for only about 0.5 million. India, China and the Philippines are the main countries of origin, together comprising nearly $50 \%$ of all Asians and $13.4 \%$ of all migrants residing in the United States (US Census Bureau, American Community Survey, 2010). Koreans and Vietnamese also constitute big communities (1,100,422 and 1,240,542), while the Pakistani community counted 300 thousand people only (in 2011).

In Canada, the top six Asian countries under analysis account for nearly one out of four migrants in the country (together comprising around 1.6 million) (Census 2006). China, India and Philippines alone represent $20 \%$ of all migrants. These three countries of origin have a stable stand in Canada, as around $30 \%$ of the population arrived in Canada before 1991. Pakistan and Korea are countries of origin of the more recent communities, as nearly $30 \%$ of immigrants from these countries came between 1996 and 2001 and even more arrived between 2001 and 2006. The Vietnamese community, instead, seems to have exhausted its growth potential as migrants arrived in a higher number at the beginning of the 1990s, while only $13.4 \%$ of the Vietnamese arrived after 1996.

Although the number of Asian migrants living in the European Union in 2010 was about 4.1 million, in relative terms, this population represented only $13 \%$ of the stock of migrants (Eurostat, 2012). ${ }^{4}$ In some countries the proportion increased to 1:4 (Demark and Sweden) and 1:5 (Czech Republic and Finland). Notably, detailed Eurostat data are not available for some relevant countries of destination such as the UK and France. ${ }^{5}$ In any case, data from the OECD confirms the UK as the main country of destination for Indians and Pakistanis, while being the second (for Philippines) and third (for Chinese) after Italy. Looking specifically at the six top Asian countries, there is a vast variety among the preferred country of residence. Italy is by far the main destination for migrants from the Philippines and India, while both Italy and Spain attract migrants from China and Pakistan. Germany is the main country of residence for Koreans and Vietnamese, though a large Vietnamese community resides also in the Czech Republic.

The main reasons for all Asians to obtain the first permit in the European Union in 2010 were education and work-related motivations (around $31.5 \%$ each) (Eurostat). In comparison with the rest of migrants in the EU, it is less likely for Asians to be in the region for family reasons, while they tend to come more frequently for educational purposes. However, there are notable differences among

\footnotetext{
4 Data extracted on the 14.08.2012.

5 No data available for Estonia, Greece, France, Cyprus, Lithuania, Luxembourg, Malta, Austria, Romania, UK.
} 
the various nationalities analyzed. Three tracks can be depicted: (1) nationals of Pakistan and Vietnam come more than others for family reunification; (2) immigrants from China and Korea come for educational reasons; (3) while Indians and Filipinos primarily arrive for employment.

Analyzing the number of permanent legal residents in Canada, the Philippines, India and China are the main overall immigration source countries. In 2010, Korea and Pakistan respectively rank at the 10th and the 11th positions, while Vietnam follows in the 31 st position in the numbers of migrants with a permanent resident status (Citizenship and Immigration Canada). Even if their numbers in absolute terms remained stable in the last decade (108.252 in 2001 and 109.448 in 2010), due to an increase in the overall number of migrants in Canada, the percentage has slightly decreased from the initial 43.2-39.0\%. However, there is significant variation between groups: in this decade, only Filipinos nearly tripled in numbers, while all other communities registered a relevant decrease. ${ }^{6}$

Estimates of the legal permanent resident (LPR) population in the US count 13.1 million people on 1 January 2011 (US Department of Homeland Security). Immediately after Mexico, the three main immigration source countries were China (0.6 million), the Philippines ( 0.6 million) and India ( 0.5 million). About two-thirds $(62.8 \%)$ of all Asians went to live in the US in 1990 or later, including over one-third $(36.2 \%)$ who entered in 2000 or later. However, it is relevant to note that Asians are among the foreign-born with the highest percentage of naturalized migrants (nearly $58 \%$ in 2010) (US Census Bureau, American Community Survey, 2010).

\section{Skill Levels and Labour Market Insertion}

Asian immigration is an important source of highly skilled (ISCED 5-6) ${ }^{7}$ migrants for developed countries. ${ }^{8}$ The largest pool comes from India, the Philippines and China (51.1, 46.0 and $39.4 \%$ respectively), as their migrants are on average more educated. Among the six countries under analysis, also Republic of Korea is a primary emigration country of the highly skilled, while migrants from Pakistan and Vietnam show a different profile with some $40 \%$ of these migrants being lowskilled (ISCED 0-2). It is also interesting to note that highly skilled workers in these countries tend to emigrate more than others, being sought-after by the destination countries. ${ }^{9}$

\footnotetext{
6 e.g. Pakistan $=-67.5 \%$; an exception to this trend is India with a nearly stable share in the total stock.

7 There are various approaches to the definition of the skill-levels of workers (and migrants). The educational approach, based on the UNESCO International Standard Classification of Education (ISCED) levels, uses education and training as a proxy of skills. Low-skilled workers are those with pre-primary and lower secondary education (ISCED 0-2), semi (or medium) skilled-workers with the upper and postsecondary education (ISCED 3-4) and highly skilled are those with tertiary education (ISCED 5-6).

8 Data in this paragraph is elaborated from OECD database, 2000.

9 This is particularly true for Asian migrants, as there is a notably difference between the total emigration rates and the emigration rates for the highly educated citizens. In 2005-06, these two rates for migrants living in OECD countries were the following for Asia and Oceania: 0.6-4.1\%; China: 0.3-1.7 \%; India: 0.4-4.2 \%; Pakistan: 0.8-5.7\%; Philippines: 4.4-8.0 \%; and especially in Vietnam: 2.9-15.4\% (data from Organisation for Economic Co-operation and Development (OECD 2012a).
} 


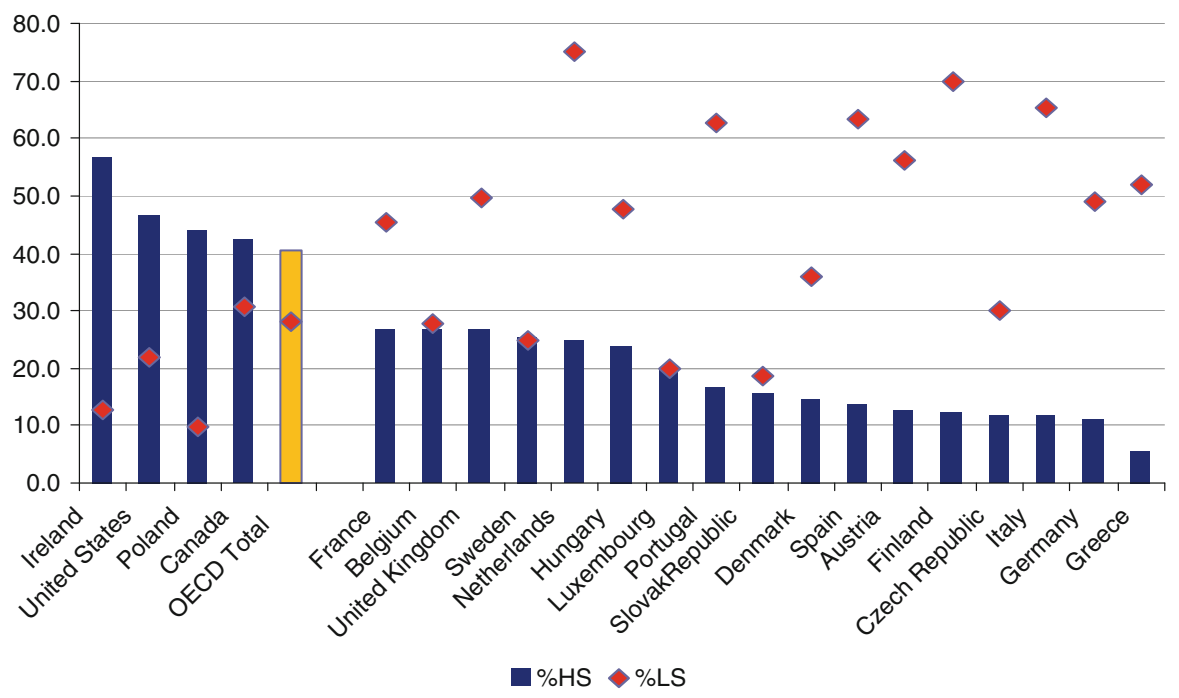

Fig. 1 Percentage of high-skilled (HS) and low-skilled (LS) Asian Migrants from the selected countries, 2000. Source: Author Elaboration on OECD database on Migration, 2000

Clearly, talent pull factors and different conditions for labour market integration have produced different outcomes in the various countries of destination. To some extent, the educational attainment of migrants is a combination of the overall education level in the country of origin and the level of selectivity on the basis of education in the country of destination. According to Barro and Lee dataset (2010), $16.2 \%$ of the adult population were highly educated in Korea in 2010, with further $22.9 \%$ in the Philippines.

In relation to the Asian migrants, only four destination countries in the EU and North America (namely Ireland, the US, Poland and Canada) predominantly attract highly skilled migrants from the analyzed six countries of origin (40\% share in the total stock from these countries or more) (Fig. 1). Recent data confirm that in 2010 around half of the foreign-born from all Asia (aged 25 or older) in the US have completed bachelor's or higher studies. By comparison, only $28.4 \%$ of native and $27.0 \%$ of the foreign-born represent the same educational level (American Community Survey, 2012). In Belgium, Sweden, Luxembourg and the Slovak Republic the numbers of highly and low-skilled migrants from these countries are quite similar, while the bulk of Asian migration here is composed of medium-skilled migrants. The Southern countries in Europe are instead attracting low-skilled Asian migrants, a percentage that overpasses the threshold of $60 \%$ in Portugal (62.6\%), Italy $(65.3 \%)$ and Spain $(63.4 \%)$. However, the highest percentage of the lowskilled Asian migrants is registered in the Netherlands $(75.1 \%)$ and in Finland $(70.0 \%)$.

These data are confirmed by recent research (OECD 2012b). According to this OECD study, in the US, Chinese and Indians each received about one in six of First Priority Green Cards, which are issued to those with extraordinary ability, outstanding researchers and top executives. In the UK, in 2009, Asians accounted 


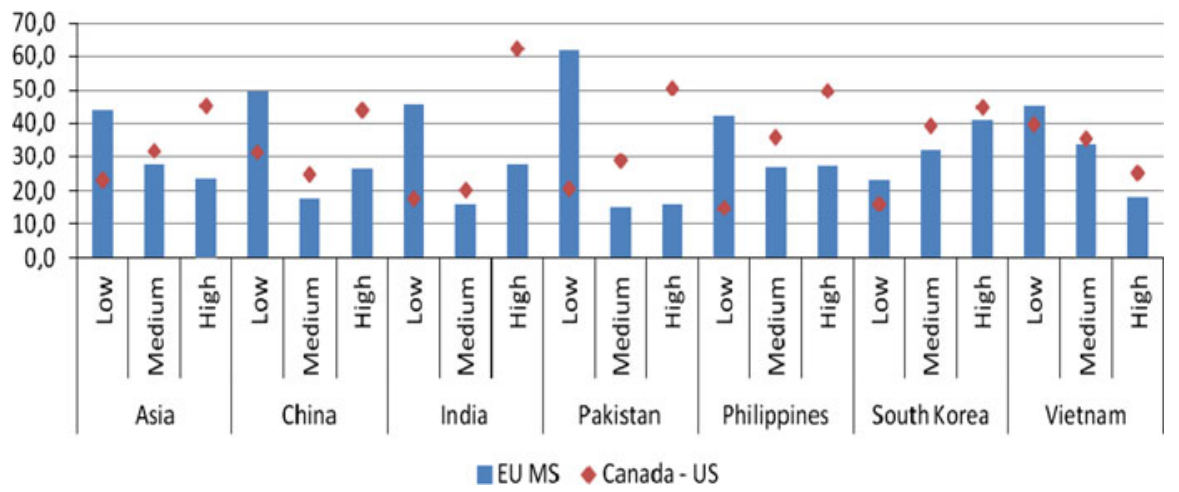

Fig. 2 Migrants from selected Asian countries by level of education (1) and country of destination (2), $\%, 2000$. Source Author elaboration on OECD database on Migration: (1) Low level equal to ISCED 0/1/ 2 level, Medium level to ISCED 3/4 level and High Level to ISCED 5/6 level, (2) EU covers the EU MS members of OECD

for more than two-thirds of entries under the immigration Tier 1 (for highly skilled migrants) and the Tier 2 (for those with a qualifying job offer).

Figure 2 provides additional insights on the different skill sets that Asian migrants bring to the countries of destination under analysis. Generally speaking, in Europe more than $40 \%$ of Asian migrants are low-qualified. The opposite scenario is detected in Canada and the US where nearly half of all Asians have high level education. While the skill composition of Korean and Vietnamese immigrant populations is quite similar in various destination countries, a significant difference is visible in the Indian and Pakistani communities, and to a certain extent also in the case of Chinese and Filipinos. More specifically, nearly $60 \%$ of Indians in Canada and US are highly educated, a figure that is only around $30 \%$ in the EU, where about half of the Indians residing in the territory have low levels of educational attainment. In the case of Pakistanis, the number of low skilled migrants of this origin in Europe is about 40 percentage points higher than in Canada and the US.

In terms of labour market insertion, the average employment rate for Asians in the OECD countries is at $57.9 \%$ and the unemployment rate at $5.1 \%$ (in 2000). However, migrants from the Philippines and India overpass the threshold of $60 \%$, while Chinese and especially Pakistanis, present a lower employment rate at 54.5 and $48.4 \%$ respectively. The different patterns of labour market integration of Asian migrants are shown in Fig. 3. At one extreme of the spectrum we find migrants from Pakistan, with low average employment rate and high unemployment rate, while on the other side migrants from the Philippines and India tend to perform much better abroad in terms of securing employment.

However, the picture of Asian immigrant integration into the labour market of the destination countries varies not only in relation to the immigrant nationality, but also to the particularities of each country of destination. For instance, Belgium, Ireland and France seem to struggle to get these migrants into jobs. On the other hand, Greece seems to have good labour market outcomes for Asian workers, although this may have more to do with high levels of irregular migration with only 


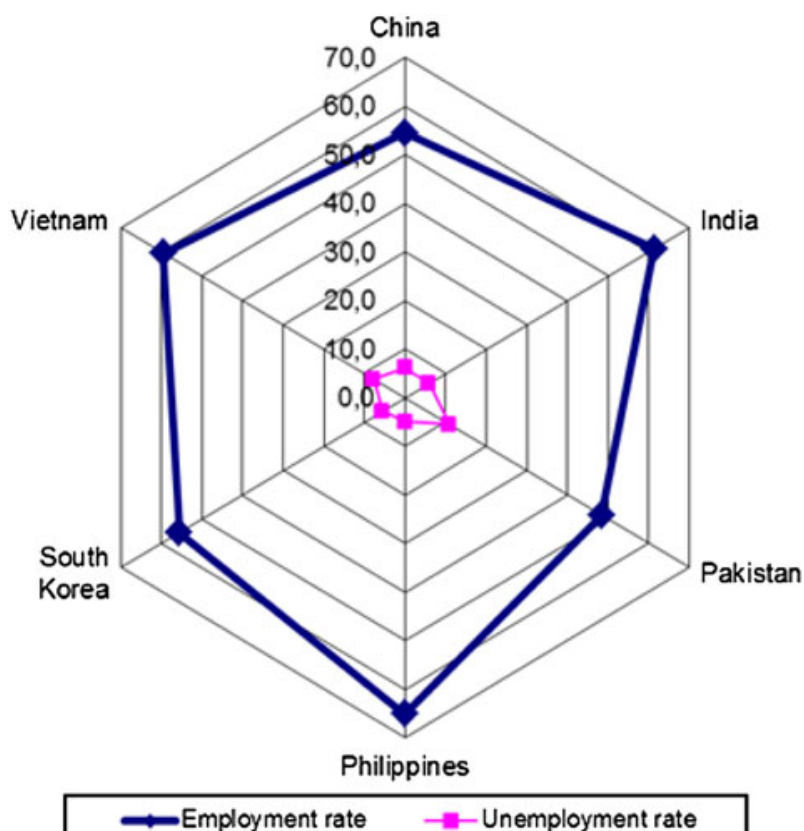

Fig. 3 Employment and unemployment rate of Asian migrants in the OECD countries, 2000. Source Author Elaboration on OECD database on Migration, 2000

few lucky migrant workers able to regularize their status. Notably, the latest comparable data by nationality is available from OECD for the year 2000, which complicates producing relevant up-to-date analysis. Some country-level data from various sources sheds additional light on the situation.

Data on employment rates alone can however be misleading as it hides the information on the actual extent to which immigrant qualifications match the skills required for the job performed. In other words, high employment rates may also conceal high levels of over-qualification and brain waste. In OECD countries the proportion of those with tertiary degrees employed in low-skilled jobs is particularly high for immigrants from Pakistan (46\%) and the Philippines (46\%). A paradox emerges as a few countries that aim to promote highly skilled immigration also see under-utilization of the human capital of migrants already residing on their territory (OECD 2012a).

Economic crisis exacerbated the position of many migrants in the labour market, particularly those in low-skilled occupations in sectors hard-hit by recession, such as construction, retail and hospitality. As underlined in recent studies of IOM LINET (see IOM 2010b; Platonova and Urso 2010a, b), self-employment became a common strategy to overcome the negative effects of the crisis among migrants from Asia in the EU. In Czech Republic, many long-term immigrants from Vietnam (79 \%) have lost their work permits. Authorities in the Czech Republic registered an increase in the number of applications for trade licences from almost 77,500 in 2007 to about 88,000 in 2009 , most of them filed by the Vietnamese in order to remain legally in the 
country (35,000: $91 \%$ of Vietnamese are trade licence holders). An increase in ethnic businesses was also registered in Italy during the economic crisis. In 2008, $18.7 \%$ most of the new registered enterprises were set up by the Chinese nationals.

In terms of sectors of employment, in 2010 around half of all Asians aged 16 and older employed in the US worked in management, business, science and arts occupations, while the average share for the foreign-born population is at $28.6 \%$. This figure reflects the inclusion of Asian migrants at the top of the American labour market hierarchy. In particular, service occupations accounted for $17.5 \%$ for Asians while the percentage rises up to $25.1 \%$ for the rest of the foreign-born. Natural resources, construction and maintenance employed only $3.4 \%$ of Asians and $13.0 \%$ of the foreign-born (American Community Survey 2012). This is not the case in country such as Italy, where most Asian migrants cover shortages in low-skilled jobs, in sectors such as agriculture and domestic care. Nationality can play a role in defining the pattern for labour market inclusion-here the initial conditions in the countries of origin could be of relevance in shaping individual migrant characteristics, but also the strength of migrant networks. Therefore, in the US in 2008, over one quarter of employed Vietnamese immigrant men worked in manufacturing, installation, and repair occupations. Nearly one of four employed Filipino-born women worked as registered nurses, and almost one-third of employed Filipinoborn men worked in health care support or in construction, extraction, and transportation. Indians, on the contrary, are more likely employed in the information technology sector (especially men), while one-third of employed Indian-born women worked in IT, management, business and finance. A similar insertion trend is visible for Chinese immigrants (MPI 2012).

Filipinos in Canada performed best among the Asian migrants with their employment rate equaling $72.8 \%$ (Canadian Census, 2006). Ageing of the baby boomers, and the consequent occupational shortages in the Canadian labour market, especially in health care professions (such as physicians, nurses and pharmacists) may have played a role in the good performance of Filipinos. Indeed, while foreign educated immigrants are less likely to find work in their trained professions, ${ }^{10}$ regulated health occupations ${ }^{11}$ generally had the highest match rates (from $84 \%$ in chiropractics to $56 \%$ in nursing) (Zietsma 2010). ${ }^{12}$ Migrants from South Asia, instead present the highest unemployment rate among Asians $(8.6 \%)$, although the figure is roughly similar to the average for other migrants (Canadian Census 2006). ${ }^{13}$ Various scenarios until 2031 (Statistic Canada 2011) project a slowdown in the labour force growth rate, largely attributable to the demographic phenomena. Consequently,

\footnotetext{
${ }^{10}$ It is interesting to note that immigrants with the highest match rates studied in English-speaking countries, a hint at the relevance of language competences.

11 For the purpose of this study, regulated occupations are those governed by provincial regulatory and/or professional associations. The study is based on 2006 Census data.

12 The same study, however, provides a synthetic match rate by country of the highest degree obtained, and the results indicate a low match rate among the six Asian countries analyzed. In particular India and Pakistan present a match rate of $21 \%$, followed by Philippines (19\%), Vietnam (17\%), China (15\%) and the Republic of Korea (12\%).

13 The Canadian Census refers to 'visible minority population', defined as 'persons, other than Aboriginal peoples, who are non-Caucasian in race or non-white colour'.
} 
the proportion of foreign born in the labour force is projected to reach about one person in three. This will certainly include a large proportion of Asians, as already now for more than 20 years immigration to Canada has mainly originated from Asia.

\section{Policy Implications}

Policy implications of the above-described trends for the main destination regions, such as North America and the EU should be considered in the light of current and projected future labour market needs and skill development perspectives. Some relevant insights are provided in this regard by the latest Manpower Talent Shortage Survey 2012 and McKinsey Global Institute report (2012b). The McKinsey forecasts in particular are corroborated on the regional level by the research carried out by the European Centre for the Development of Vocational Training (CEDEFOP) in the EU (CEDEFOP 2011). In particular, both studies confirm the existing polarization of the labour market with growing demand in highly skilled and low-skilled occupations, with the forecast projecting the exacerbation of this trend in the future.

Furthermore, Manpower survey highlights acute talent shortages in all global regions, including Asia Pacific. Some $81 \%$ of employers in Japan and $48 \%$ in India report hiring difficulties. Ageing workforce is already a challenge across the developed world, and is increasingly an issue facing in the nearest future many economies in the Asian region, including China. Severe shortages are also reported in Brazil-another emerging global talent magnet-where $71 \%$ of employers find it hard to recruit relevant staff compared with $49 \%$ in the United States. Labour markets in Europe are still suffering from recession, although shortages persist in some sectors. Even in Greece, nearly one out of four employers reported recruitment difficulties to Manpower, $42 \%$ of employers are struggling in Germany, but only 14 $\%$ of Italian employers did so. Engineering is second only to skilled trades as a sector where workers are in short supply, with shortages in STEM (science, technology, engineering and math) occupations being reported in every region.

Reported employer strategies to tackle shortages confirm that immigration is one of the options considered irrespective of the region. Some $28 \%$ of the US employers look for staff outside their local region, but also one in eight employers in Asia Pacific. At the same time, $27 \%$ of Chinese employers choose to offer higher salaries to become more competitive in the labour market (compared to $16 \%$ in the US), which is a notable trend that could hamper future emigration from the region, as well as impact on the processes of diaspora return and attracting foreign talent to Asia (ManpowerGroup 2012).

Future forecasts by McKinsey suggest that by 2020 the US may have a shortage of 1.5 million with college or graduate degrees and France may be lacking 2.2 million workers with a baccalaureate to meet demand in 2020. Other developed countries show similar trends, but skilled labour is increasingly in demand across the globe as noted above, coupled with strong economic growth in Asian, Latin American, but also some African countries. Scarcity of skills and increasing opportunities for mobility already lead to a greater diversity of flows between and 
within the global regions. Severe recession in Southern Europe resulted in recent young and skilled emigration from these countries to such diverse destinations as Brazil, Angola and Australia.

In this light, immigration could become an ever more important tool in tackling skill shortages in countries at various stages of economic development. Provisions for admission and stay in the national immigration regimes, but also immigrant integration opportunities and overall attractiveness of individual countries could hence play an important role in the future workforce policies.

National immigrant admission policies provide a crucial starting point for labour market integration in particular, as they regulate the possibilities and limitations to labour market access. IOM LINET ${ }^{14}$ assessment of the admission regimes across the EU concludes that the process in many countries remains time-consuming, complex and costly, which at times pushes employers and migrants towards irregular channels. Economic migrants are often trapped in the temporary employment status, which ties them up to specific employers and occupations, thus increasing dependency and vulnerability. Moreover, family and humanitarian migrants also face restrictions to their labour market access with evident negative impact on their future labour market perspectives.

Preferential treatment of specific categories of immigrants is a complex decision. Evidence on the better labour market outcomes of the 'economic' stream migrants is to be corroborated by wider considerations of upholding migrants' rights for family reunification and humanitarian commitments of states. At the same time, in countries such as the US, family migration is a significant contributor to meeting labour market needs at various skill levels. Opportunities for spouses and other family members may also prove to be the decisive factor in the choice of the country of residence by the highly skilled migrants in particular.

Nevertheless, preference for the highly skilled workers is prevalent in the immigration policies of the developed countries, as these migrants are expected to have a significant effect on growth and innovation. Points-based systems are popular (also adopted by Singapore, Korea and Japan), but are increasingly complemented by employer-led admission channels, which ensure early labour market insertion. These measures are aimed to counterbalance the worsening labour market outcomes of 'points migrants' (as in the case of Canada), but also to provide employers with a fasttrack access to global labour (as in Australia). At the same time, Sweden decided against any differentiation by skill level in its admission frame work, thus fully delegating the decision to employers as long as the job offer meets the Swedish labour standards. At the same time, Canada also introduced various schemes for temporary labour migration in agriculture and caregiving, albeit with some pathways towards permanent residency in recognition of the long-term character of labour demand also in less skilled occupations (see Platonova and Urso 2012). Immigrant entrepreneurship and investment is another area for immigration policies, but overall economic dynamism and vitality are crucial in this regard. Increasingly, these policies are not just prerogatives of the traditional skilled immigration destinations, but are increasingly developed and applied in Asia and elsewhere (see OECD 2012b).

$\overline{14}$ More info at http://www.labourmigration.eu. 
Evidently, student mobility policies may underpin efforts of the countries seeking to attract skilled labour. Students who choose to stay and work in the country of destination after the graduation may avoid some of the problems plaguing other migrants, such as recognition of qualifications, language skills and access to social and professional networks. This strategy could be of interest particularly to smaller destination countries with less widespread languages and limited economic clout compared to the main global talent magnet countries. For the EU this could be a relevant direction of action, given the relatively high share of students in Asian immigration flows compared to other categories. However, apart from clear pathway from studies to work, this approach would first and foremost entail efforts towards strengthening and internationalisation of the national education systemswhich is incidentally a crucial measure to ensure upskilling of own population and improve linkages between the education system and the labour market.

Diaspora return proves to be an important element of particularly India's and China's skilled labour supply. However, here economic opportunities prove to be the primary pull factor above any incentives provide by the state (OECD 2012a, b).

The European Union, in particular, currently seems to lose out to other global migration destinations in terms of attracting highly skilled Asian migrants, as corroborated by the data presented in this article. There is an urgency to address integration challenges in relation to migrants already residing in the EU as various labour market barriers, including discrimination, difficulties in recognition of qualifications but also rigidity of the labour markets result in high levels of overqualification and underemployment for many Asian migrants (Platonova and Urso 2010a, b). These trends result in deskilling and brain waste among immigrant population, which in turn also diminish the opportunities of the countries of origin to benefit from diaspora potential for development.

Any general comparisons between the EU and North America in terms of immigrant integration inadvertently ignore the vast diversity among the EU Member States in terms of labour market regulation and structures, immigration policy setup, immigration history and overall societal environment, including attitudes towards immigration. However, by and large the conditions for immigrant integration offered by the EU countries seem to be less conducive to positive outcomes (for example, see Picot and Sweetman (2011) for comparison between Canada and Sweden). Importantly, not only overall dynamism of the labour markets, but also the societal attitudes towards diversity are of relevance not only for improving the outcomes of the already residing migrants, but to attract future migrants of relevant skill levels, particularly the highly skilled.

The global competition for talent that will intensify in the future and demographic and economic trends in Asia suggest that developed countries will be and at times already are not just competing among themselves for the highly skilled workers, but competing with the growing economies in Asia and elsewhere. In-depth comparative analysis of immigration and integration patterns of various groups in the key countries and regions could offer the policymakers useful insights on attracting workers with relevant skills and creating conditions to both maximize their economic contribution and support social cohesion. 


\section{References}

International Organization for Migration (IOM) (2003) Labour Migration in Asia. Trends, Challenges and Policy Responses in Countries of Origin. IOM, Geneva

International Organization for Migration (IOM) (2010a) The future of migration policies in the Asiapacific region, background paper word migration report. IOM, Geneva

International Organization for Migration (IOM) (2010b) Migration and the economic crisis in the European Union: implications for policy. IOM LINET, Brussels

International Organization for Migration (IOM) (2012a) Highly skilled migration and student mobility between Asia and Europe: framing the discussion. In Background note, 11th ASEM Conference, 30-31 October 2012, Nicosia

International Organization for Migration (IOM) (2012b) Labour migration from Colombo process countries: good practices, challenges and way forward. IOM Geneva

ManpowerGroup (2012) Manpower Talent Shortage Survey 2012, Milwaukee USA

McKinsey Global Institute (2012a) The world at work: jobs, pay, and skills for 3-5 billion people. http://www.mckinsey.com

McKinsey Global Institute (2012b) Help wanted: The Future of Work. http://www.mckinsey.com

Migration Policy Institute (MPI) (2012) Migration Information Source. Country Profiles. http://www. migrationinformation.org

Organisation for Economic Co-operation and Development (OECD) (2012a) Connecting with emigrants. A global profile of diasporas, OECD Paris

Organisation for Economic Co-operation and Development (OECD) (2012b) International Migration Outlook. Sopemi 2012. OECD Paris

Picot G, Sweetman A (2011) Canadian Immigration Policy and Immigrant Economic Outcomes: Why the Differences in Outcomes between Sweden and Canada? IZA Policy Paper No. 25

Platonova A, Urso G (eds) (2010a) Migration, employment and labour market integration policies in the European Union (2000-2009). Part 1: Migration and the Labour Markets in the European Union (2000-2009). IOM LINET, Brussels

Platonova A, Urso G (eds) (2010b) Migration, employment and labour market integration policies in the European Union (2000-2009). Part 2: Labour Market Integration Policies in the European Union (2000-2009). IOM LINET, Brussels

Platonova A, Urso G (2011) Recent migration from the colombo process countries to the European Union. Background paper, Asia-EU Dialogue on Labour Migration, 8-9 February 2011, Brussels

Platonova A, Urso G (eds) (2012) Labour shortages and migration policy. IOM LINET, Brussels

Ratha D (2012) Global prospects for migration and remittances in 2012: Implications for Asia, ADBIOECD Roundtable on Labour Migration in Asia, 18-20 January 2012, Tokyo

Statistics Canada (2011) Projected trends to 2031 for the Canadian labour force. Canadian Economic Observer, $24 / 6$

United Nations, Department of Economic and Social Affairs (UN DESA) (2005) World population prospects: the 2004 revision, vol III: analytical report. Population Division, New York

United Nations, Department of Economic and Social Affairs (UN DESA) (2009a) International Migration, 2009 Wallchart. Population Division, New York

United Nations, Department of Economic and Social Affairs (UN DESA) (2009b) World population prospects: the 2008 revision. Population Division, New York

United Nations, Department of Economic and Social Affairs (UN DESA) (2010) Population Facts. No.2010/6, UNDESA/Population Division

World Bank (2012) Migration and Development Briefs 18. Migration and Remittances Unit, Washington DC

Zietsma D (2010) Immigrants working in regulated occupations. Perspectives on Labour and Income. Statistics Canada Catalogue no 75-001-XIE vol 11(2) 